\title{
ON THE QUESTION OF DEFINITION OF THE SUBJECT AREA OF RESEARCH IN THE SPECIALTY "GEODESY AND LAND SURVEYING"
}

Andrii MARTYN, Corresponding Member of NAAS of Ukraine, Doctor of Economics, Professor, National University of Life and Environmental Sciences of Ukraine e-mail:martyn@nubip.edu.ua

Ihor TREVOGO, Doctor of Technical Sciences, Professor, Lviv Polytechnic National University, President of the Ukrainian Society of Geodesy and Cartography e-mail: itrevoho@gmail.com

Taras IEVSIUKOV, Doctor of Economics, Professor, National University of Life and Environmental Sciences of Ukraine, Deputy Chairman of the Board of the NGO "Association of Land Management Specialists of Ukraine" e-mail:ievsiukov_t@nubip.edu.ua

Khrystyna BURSHTYNSKA, Doctor of Technical Sciences, Professor, Lviv Polytechnic National University e-mail: bursht@polynet.lviv.ua

Abstract. The article discusses the content of the subject area introduced in 2015 in Ukraine specialty "Geodesy and Land Surveying" as a set of all subjects, the properties of which and the relationship between which should be considered in the relevant scientific theory. Based on the established practice of research work, as well as international approaches to determining the subject of modern geodesy and land surveying, it is proposed to identify six subsets of research areas (specializations): geodesy; aerospace research of the Earth, photogrammetry and geoinformatics; cartography; land cadastre; land surveying; land administration. For each of the subsets of the subject area of research, a detailed description of the subject orientation is proposed, which allows to specify the context and content of the relevant research. A detailed description of the subject area of knowledge allows to simplify for applicants for scientific degrees and their supervisors the choice of the desired field of research, as well as the process of preparation and execution of documents. A clear delineation of the subject area of the field of knowledge also allows higher education institutions to more effectively develop the relevant educational programs, to develop the professional sphere 
of their operation. Editorial boards of professional scientific journals can use the description of the subject area of the field of knowledge to establish the correspondence of the articles of specialization of such publications submitted by the authors.

Key words: geodesy, land surveying, subject area, field of research, doctor of philosophy, higher education.

Problem description. Each scientific discipline is determined by its own logical system of scientific knowledge, methods and means of cognition, which are constantly evolving. A characteristic feature of the scientific discipline is the development of its own conceptual apparatus, justification of specialization of concepts and language of science, increasing the information field of scientific concepts, deepening their content and narrowing their scope. Each specific science is marked by a certain isolation of the knowledge system, has the integrity and openness of content, which allows to expand it with new scientific facts, laws, theories and more.

Defining the subject area of research is an important element of the organization of scientific and educational work within a particular scientific specialty or field of knowledge. Despite the fact that there is currently no generally accepted formal definition of "subject area of knowledge", the authors consider it as a set of all subjects, the properties of which and the relationship between which take place in the relevant scientific theory. Clear delineation of the subject area of knowledge plays an extremely important role in the preparation and certification of higher education and scientific personnel of higher qualification, planning and implementation of research work, reviewing scientific publications, development of targeted scientific and technical programs in relevant fields and more. A detailed description of the subject area of knowledge allows to simplify the degree and the process of preparation and execution of documents. A clear delineation of the subject area of the field of knowledge also allows higher education institutions to more effectively develop the relevant educational programs, to properly develop the professional sphere of their operation. Editorial boards of professional scientific journals 
can use the description of the subject area of the field of knowledge to establish the correspondence of the articles of specialization of such publications submitted by the authors.

Specialty 193 "Geodesy and Land Surveying" within the field of knowledge 19 "Architecture and Construction" was first introduced in the List of branches of knowledge and specialties for which higher education is provided, approved by the Cabinet of Ministers of Ukraine dated April 29, 2015 № 266. In In this article, the author's team on the basis of established practice of research work, as well as international approaches to defining the subject of modern geodesy and land management, for the first time offers a description of the subject area of research in the specialty.

Analysis of recent research and publications. The work of many well-known Ukrainian land geodesists and land surveyors, in particular, S. Voitenko [1], D. Dobryak [2], A. Martyn [3], R. Sossa, I. Trevoho [4], which explored the prospects for the development of geodetic and land surveying professions.

To outline the subject area of research in the specialty "Geodesy and Land Surveying" undoubtedly of interest are also passports of certain scientific specialties, defined by the order of the Ministry of Education and Science, Youth and Sports of Ukraine from 14.09.2011 № 1057 (in particular: 05.24.01 - Geodesy, Photogrammetry and Cartography ${ }^{1}, 05.24 .04$ - Land Cadastre and Monitoring ${ }^{2}$, 05.23.20 - Urban Planning and Spatial Planning ${ }^{3}$, 08.00.06 - Economics of Nature Management and Environmental Protection $\left.^{4}\right)$.

On May 23, 2004, the General Assembly of the International Federation of Surveyors (FIG) adopted a description of the surveyor as a professional person with the academic qualifications and technical expertise to conduct one, or more, of the following activities;

\footnotetext{
${ }^{1}$ Resolution of the Presidium of the Higher Attestation Commission of Ukraine dated 14.06.2007 № 47-08/6.

${ }^{2}$ Resolution of the Presidium of the Higher Attestation Commission of Ukraine dated 09.04.2008 № 23-08/4.

${ }^{3}$ Resolution of the Presidium of the Higher Attestation Commission of Ukraine dated 21.05.1998 № 25-08/5.

${ }^{4}$ Order of the Ministry of Education and Science of Ukraine dated 29.12.2014 № 1528, Annex 13.
} 
- to determine, measure and represent land, three-dimensional objects, pointfields and trajectories;

- to assemble and interpret land and geographically related information,

- to use that information for the planning and efficient administration of the land, the sea and any structures thereon; and,

- to conduct research into the above practices and to develop them.

In the context of land surveyors' activity, the report " European requirements for cadastral surveyor activities" [6], prepared jointly by EuroGeographics (www.eurogeographics.org), the Comité de Liaison des Géomètres Européens (CLGE, www.clge.eu) and Geometer Europas (www.geometer-europas.eu), deserves special attention. This study was the result of the EuroGeographics seminar " The role of land surveyors in the maintenance of cadastre", organized in Vilnius (Lithuania) on March 2324, 2006. The survey showed that the tasks of cadastral engineers in the EU include: cadastral (technical) field surveys (24\%), marking turning points of plot boundaries (23\%), advising landowners (21\%), validation / approval of cadastral plans with relevant authorities (20\%), land valuation (11\%), registration or updating of data in the cadastral database (8\%), determination of restrictions on land use (7\%), preparation (adjustment) of spatial planning documents $(6 \%)$, other activities $(5 \%)$.

The purpose of the study is to determine on the basis of established practice of research, as well as international approaches to the subject of modern geodesy and land management, the content of the subject area of research specialty "Geodesy and Land Surveying" as a set of all subjects.

Materials and methods of research. The study used methods of modeling, comparison and generalization, analysis, synthesis. The theoretical basis for the study were the current regulations defining the subject area of research in the field of geodesy and land surveying, including passports of scientific specialties, recommendations of international professional organizations, research of scientists on theoretical and 
scientific-methodological principles of scientific and educational work in the field of geodesy and land surveying.

Research results and their discussion. Accordingly, the professional tasks of surveyors, according to FIG [5], may include one or more of these activities carried out on, above or below the surface of the land or sea, in particular in conjunction with other professionals:

1. The determination of the size and shape of the earth and the measurement of all data needed to define the size, position, shape and contour of any part of the earth and monitoring any change therein.

2. The positioning of objects in space and time as well as the positioning and monitoring of physical features, structures and engineering works on, above or below the surface of the earth.

3. The development, testing and calibration of sensors, instruments and systems for the above-mentioned purposes and for other surveying purposes.

4. The acquisition and use of spatial information from close range, aerial and satellite imagery and the automation of these processes.

5. The determination of the position of the boundaries of public or private land, including national and international boundaries, and the registration of those lands with the appropriate authorities.

6. The design, establishment and administration of geographic information systems (GIS) and the collection, storage, analysis, management, display and dissemination of data.

7. The analysis, interpretation and integration of spatial objects and phenomena in GIS, including the visualisation and communication of such data in maps, models and mobile digital devices. 
8. The study of the natural and social environment, the measurement of land and marine resources and the use of such data in the planning of development in urban, rural and regional areas.

9. The planning, development and redevelopment of property, whether urban or rural and whether land or buildings.

10. The assessment of value and the management of property, whether urban or rural and whether land or buildings.

11. The planning, measurement and management of construction works, including the estimation of costs.

Taking into account these international approaches to defining the subject of modern geodesy and land management, as well as established research practice, the authors of the article in the order of discussion propose to identify six subsets of research (specializations) within the specialty "Geodesy and Land Surveying", namely: geodesy; aerospace research of the Earth, photogrammetry and geoinformatics; cartography; land cadastre; land surveying; land administration.

For each of the subsets of the subject area of research, we have proposed a detailed description of the subject orientation, which allows you to specify the context and content of the relevant research:

\section{Geodesy}

Specialization - determination of the shape and size of the Earth, its gravitational field, rotational motion of the Earth, spatial characteristics of natural and man-made objects, phenomena and processes on its surface, creation of geoinformation space as a basic product of geodetic support, as well as establishing patterns of space changes.

Subject orientation:

1) theoretical geodesy - space-time coordinate systems, study of the Earth's external gravitational field (physical geodesy), representation of the Earth's shape in the form of 
an ellipsoid of rotation and determination of its parameters (spheroidal and spatial geodesy).

2) basic geodetic works - means and methods of geodetic measurements, astronomical observations and global positioning systems, creation and development of geodetic networks and networks of base GNSS stations as a basis for geodetic works in the country;

3) marine geodesy - determination of sea levels, means and methods of measurements for navigation of sea vessels, creation of sea maps, removal of the shelf and seabed;

4) geodetic astronomy - means and methods of astronomical determination of the position of points and directions, the system of determining the time of diurnal rotation of the Earth, the system of spherical celestial coordinates and the system of time;

5) gravimetry - measurement of gravity and other derivatives of gravity potential (gravity transformants);

6) space geodesy - geodetic use of artificial satellites of the Earth, the use of radio interference observations on an ultralong basis for geodetic networks;

7) geodetic methods for solving geodynamic problems - programs of geodynamic observations using geodetic methods, study of planetary geodynamic phenomena, modern movements of the earth's crust, the internal structure of the Earth using geodetic and gravimetric data;

8) topographic measurements; military topographic support;

9) topographic surveys, aerial surveys, aerotriangulation, aerial photography and photogrammetric works, topographic and special maps, digital terrain models, the use of aerospace information in geodesy and cartography; military topographic support;

10) surveying spatial and geometric measurements in the bowels of the Earth during their exploration and development and on the surface of mines and quarries, surveying surveys during the construction and operation of underground structures;

11) engineering geodesy - the use of geodesy for topographic and geodetic surveys, high-precision measurements and geodetic monitoring in the field of construction, energy, 
transport, for the rational use of nature in the search and development of deposits in land management and cadastre, forestry and water management, science and other industries .

13) mathematical processing and analysis of the results of geodetic measurements mathematical and static methods of their processing, computational methods for solving geodetic problems, software products, accuracy assessment, models and methods of storing geodetic information;

13) modern systems of accumulation, processing, storage, transmission and use of geodetic information, including geodata formats, infrastructure and territorial geodetic data banks, electronic databases of geodetic knowledge, geoservices, geoservices, geoportals and other geodetic systems on the Internet;

14) instrument and technical support of geodetic measurements - modern measuring technological systems, installations and devices (satellite signal receivers, interferometers, gravimeters, trackers, robotic electronic total stations, digital levels, georadars, scanners, echo sounders, inclinometers, gyrotheodolites, etc.), ;

15) geodetic metrology - development of methods, means and normative documents for metrological research of geodetic means of measurements; creation and operation of reference geodetic polygons, bases and comparators for verification, calibration and conformity assessment of geodetic measuring instruments.

\section{Aerospace Earth Research, Photogrammetry and Geoinformatics}

Specialization - the content of aerospace research, principles, methods, technologies and technical means of determining the size, shape, position in space, as well as mapping of the Earth's surface, landscape complexes and any objects, including artificial structures in a contactless way from their images obtained in different parts of the spectrum of electromagnetic oscillations. Study of general properties of geoinformation, patterns and methods of its receipt, fixation, accumulation, processing and use, as well as development of theory and technologies of geoinformation systems to collect, systematize, store, analyze, transform, display and disseminate spatially coordinated data. 
Subject orientation:

1) remote sensing of the Earth (remote sensing) - methods of remote sensing of objects, processes and phenomena according to their terrestrial and aerospace images; methods of DR for solving thematic tasks and territory management;

2) the physical basis of remote sensing;

3) aerospace imaging complex, aerospace equipment carriers, types of space aircraft;

4) filming equipment, types and schematic diagrams of filming systems: photographic, television, optoelectronic, laser, radar and others;

5) metrology of shooting systems, transfer properties of images;

6) photogrammetry and phototopography, aerial photography, aerotriangulation, aerial photography and photogrammetric works, topographic and special maps, digital terrain models, use of aerospace information in geodesy and cartography;

7) means of ground and aerospace survey; theoretical bases and technologies of processing of photographic, television, optoelectronic, laser, radar multizonal and other images; construction of digital models of objects, terrain, relief; phototriangulation; basic problems of space photogrammetry, equations of space photogrammetry;

8) theory, technology, processing of aero- and space images, technical means of condensation on aerospace images of geodetic networks, digital photogrammetric and geoinformation methods of creating and updating topographic, land management, ecological, cadastral and other maps and plans;

9) theory and technology of image decoding and pattern recognition for the purpose of research of natural resources and mapping of research objects;

10) space photogrammetry, the main tasks of space photogrammetry;

11) photogrammetric instrumentation - design of measuring instruments and systems, digital photogrammetric stations, research of instruments and systems for obtaining and processing measuring information; processing of measurement results with the use of mathematical methods; 
12) information technologies for the creation of models of the earth's surface and planets and their presentation in digital form, as well as on plans, maps, profiles and other geoimages;

13) theory and technology of obtaining spatio-temporal and quantitative characteristics of the dynamics of natural and man-made processes by complex geodetic, photogrammetric methods and data of remote sensing of the Earth for the purpose of their forecast estimation;

14) geoinformation systems and technologies, geospatial data infrastructures; geospatial databases and metadata; methods, models and technologies of formation, processing, storage, distribution and use of geospatial data on the basis of distributed databases and knowledge, local and global information networks, development of geoinformation portals, modeling of geosystems;

15) standardization of geographical information, methods of geocoding, geoinformation services, models of digital coding and digital representation of geospatial data, geoimages, digital and electronic maps and plans, metadata, methods and means of exchange of geographical information;

16) principles, methods, procedures and technologies for quality assessment and conformity assessment of geospatial data, digital and electronic maps and plans.

\section{Cartography}

Specialization: modeling of geosystems, study, creation and use of maps, photographs, atlases and other cartographic works in traditional paper and electronic forms, general theory of cartography.

Subject orientation:

1) general theory of cartography - the development of the doctrine of its subject, working model, methods, cartographic languages and their grammars; theory of cartographic projections and other problems of mathematical cartography; cartographic toponymy; cartographic generalization; cartographic design; 
2) new methods of compiling and designing maps, new types of topographic, general geographical and thematic maps and atlases; geoinformation mapping; technologies of publishing maps, organization of geodetic and cartographic production;

3) the use of maps in science and practice, military affairs, cartometry, mathematical and cartographic modeling, accuracy and reliability of research on maps;

4) history of cartography, design and mapping, map publishing technology, basics of cartographic modeling, GIS and database in cartography, web-cartography, cartographic research method, mathematical cartography, topographic mapping, mathematical processing and programming;

5) history of geodesy, cartography, photogrammetry and cartographic source studies.

6) mathematical cartography, mathematical processing and programming;

7) cartographic method of research of objects, processes and phenomena; mathematical and cartographic modeling, accuracy and reliability of research on maps ; design and compilation of maps;

8) topographic mapping;

9) new methods of compiling and designing maps, new types of topographic, general geographical and thematic maps and atlases; geoinformation mapping;

10) basics of cartographic modeling, GIS and databases in cartography, webcartography;

11) technologies of map issuance, organization of geodetic and cartographic production;

12) the use of maps in science and practice, military affairs.

\section{Land Cadastre}

Specialization - study of methods and technologies of accounting, registration, collection, processing and use of information on the state of land resources and real estate, maintenance of natural resources, modeling of real estate and territories, monitoring, evaluation and forecast of land resources. 
Subject orientation:

1) methodological bases of construction of cadastral systems; cadastre as a basis for state registration of rights to land and other real estate; definition and optimization of objects of cadastral accounting, their characteristics for registration in cadastral systems; registration of rights of individuals and legal entities to real estate, as well as public rights, restrictions and encumbrances on the possession and use of real estate;

2) regulatory and legal and institutional support for the formation of the system of state land cadastre and real estate cadastre, cadastres of natural resources; 3D / 4D cadastre; point cadastre; multifunctional cadastre; world experience in creating cadastral systems; blockchain technology in registration systems;

3) methods and technologies of collection, documentation, registration, processing and storage of information on land and real estate; technical inventory of buildings and structures;

4) substantiation of the accuracy of surveying the spatial characteristics of cadastral objects, methods of calculating their areas, selection of optimal coordinate systems and projections for registration of cadastral objects;

5) informatization of cadastral activity, development of automated cadastral systems; information technologies of land cadastre maintenance; standardization of structure and information models of databases of cadastral and monitoring systems; unification of the system of electronic documents of cadastral systems and development of distributed systems of their formation, processing and use; integration of cadastral systems into the national geospatial data infrastructure.

6) scientific and methodological support for the assessment of land and other real estate, land market research and assessment zoning of territories; determination of townplanning value of lands of settlements; evaluation automation and computer models in evaluation activities; market environment monitoring and real estate market forecasting systems; 
7) cadastral, economic-planning, functional, engineering-geological, historicalcultural, sanitary-hygienic, ecological, landscape and other types of thematic zoning of territories;

8) scientific bases of comparative assessment of soil fertility (soil grading); agroindustrial grouping of soils; improvement of methods and technologies of soil surveys, assessment of soil condition for the purposes of monetary valuation of lands;

9) use of cadastral information for assessment and forecast of the state of the environment, information support of the real estate market and sustainable land use;

10) investment analysis and financial and economic activities in the real estate market;

11) monitoring of lands and natural resources; urban planning, price, geomorphological, geoecological, landscape and other types of monitoring of lands and related natural resources and man-made processes; substantiation of the system of controlled indicators and the network of land monitoring facilities; methods of ground and remote monitoring of lands, natural resources and natural-territorial complexes; geoecological monitoring and certification of lands, built-up areas, engineering and natural objects.

\section{Land Surveying}

Specialization - substantiation of engineering decisions on integrated use of land, water, forest resources, regulation of urban systems, conservation of biodiversity and natural resources to meet human needs, study of methods and technologies of spatial planning, land management, formation of rational land use system, settlement planning administrative-territorial units, transport and ecological planning, definition of territories with special land use conditions.

Subject orientation:

1) development of all types of land management documentation at the national, regional and local levels; establishment and change of boundaries of land management objects, including determination and establishment in kind (on the ground) of the state 
border of Ukraine; granting, withdrawal (redemption), alienation of land plots; establishment in kind (on the ground) of the boundaries of lands restricted in use and limited (encumbered) by the rights of other persons (land easements); organization of new and streamlining of existing land management facilities;

2) reclamation of disturbed lands and lands affected by negative processes and measures to restore or conserve them, reclamation of disturbed lands, land of unproductive lands, protection of lands from erosion, flooding, waterlogging, secondary salinization, drying, compaction, pollution by industrial waste, radioactive and chemical substances and other types of degradation; conservation of degraded and unproductive lands;

3) distribution of land by purpose, taking into account state, public and private interests, the formation of a rational system of land tenure and land use, the creation of ecologically sustainable agricultural landscapes;

4) establishment and consolidation on the territory of the boundaries of administrativeterritorial units, territories of the nature reserve fund and other nature protection purposes, health, recreational and historical-cultural purposes, the boundaries of land plots of owners and land users;

5) forecasting, planning and organization of rational use and protection of lands at the national, regional, local and economic levels;

6) consolidation of agricultural lands; organization of the territory of agricultural enterprises, institutions and organizations in order to create spatial conditions for ecological and economic optimization of use and protection of agricultural lands, introduction of progressive forms of land use management, improvement of structure and placement of lands, sown areas, crop rotation, hay and pasture change;

7) development and implementation of a system of land management measures for the preservation of natural landscapes, restoration and increase of soil fertility, reclamation of disturbed lands and land of unproductive lands, protection of lands from erosion, flooding, drying, landslides, secondary salinization, acidification, waterlogging, compaction, 
pollution waste and chemicals, etc., conservation of degraded and unproductive lands, prevention of other negative phenomena;

8) organization of the territory of enterprises, institutions and organizations in order to create conditions for sustainable land use and the establishment of restrictions and encumbrances (land easements) in the use and protection of land;

9) historical preconditions of land management; content and trends in land development at different historical stages; main directions of land management and spatial planning improvement;

10) planning and improvement of settlements; design of streets and roads; engineering preparation of urban areas; maintenance of urban development;

11) regional planning; formation of a territory development strategy to ensure the creation and maintenance of a full-fledged living environment, rational use of available resources, reduction of potential risks, strengthening the inherent advantages of the territory, balancing various economic, social, cultural, environmental and other needs; sustainable development of territories;

12) economic aspects of land management; economic and mathematical substantiation of design decisions in land management; compensation for losses of agricultural and forestry production; compensation for losses of landowners and land users; determination of the fee for the establishment of land easements;

13) development of town-planning documentation; urban development projects of cross-border regions, planning schemes of separate parts of the territory of Ukraine, planning schemes of oblasts, districts, general plans of settlements, zoning plans and detailed plans of territories;

14) project decision support systems; design automation (CAD); automated designer locations and interactive graphics systems;

15) survey during land management;

16) organization of land management works; budget case; quality management of land management works; examination of land management documentation; author's 
supervision over the implementation of land management projects; copyright in land management; state and self-government control over the implementation of land management;

17) the latest technologies in spatial planning; extended spatial analysis; multi-agent systems; spatial optimization models; system dynamic models; virtual worlds; methods of visualization of design decisions; web-services in planning; crowdsourcing in planning.

\section{Land Administration}

Specialization - studying the principles of formation and implementation of land policy and regulation of land relations based on the establishment of special rules for the alienation of land rights through sale, lease, mortgage, gift and inheritance; regulation of the land and real estate market; sales, rent and tax revenue management; conflict resolution over land ownership and use; legal, regulatory, fiscal and information tools for land administration.

Subject orientation:

1) organization of land resources management - development of land policy; the role of government in land management; interdepartmental coordination; the role of the public and private sectors in land management; payment for land management; e-government and commerce in land relations; land information management;

2) management in land management - organizational issues of institutions in the field of land management; business plan development; centralization and decentralization; funding and sources of assistance in systems modernization, research and development; measuring the costs of land management and management of land registration and cadastre data and their marketing; transition to full reimbursement; formation of the image of the organization; data exchange and e-government; electronic document management; human resources management (training and education, people management, work with the private sector); 
3) land as a basis for sustainable development; experience of land reforms; benefits of an effective land management system; problems of land privatization; land relations and overcoming poverty;

4) institutional issues of land management - the system of legal regulation of land relations; legal titles of land ownership and use; land rights protection system;

5) management of public lands - organization of access to public lands; theoretical principles and procedure for holding land auctions and competitions; publicity of information on land management; revenue management from the use of public lands;

6) management of conflicts related to access to land resources (global migration flows, climate change, military conflicts); settlement of land disputes; mediation in land disputes;

7) expropriation and public interests in land use - the procedure for forced alienation of land and other real estate for public needs or for reasons of public necessity; requisition of land plots during special or martial law;

8) regulation of the transfer of the right to real estate, sale, lease of real estate regulation of economic turnover of agricultural land, corporate restrictions, access to the land market for foreigners;

9) fiscal regulation of land relations - the system of property taxes; land tax; tax on real estate other than land; land and real estate tax base; special tax regimes in agriculture;

10) organization of mortgage lending, the procedure for compulsory alienation of land and other real estate; financial and economic aspects of the mortgage; forms and mechanisms of state support of mortgage lending;

11) e-government and public services - the functioning of the public services portal; permit system in the field of economic activity; administrative services in the field of land relations;

12) state control (supervision) in the field of rational use and protection of lands organization of state control (supervision) bodies; liability for violation of land legislation; the procedure for conducting inspections of land and environmental legislation; state geodetic supervision over topographic-geodetic and cartographic activities; calculation of 
the amount of damage caused as a result of unauthorized occupation of land plots, their misuse, removal of soil cover without a special permit and other violations;

13) development activity - legal and regulatory problems during real estate development; development and financing of a development project; development project management;

14) budgeting in the field of land management; organization of planning and financial work in land management bodies, enterprises, institutions and organizations; control over the targeted use of financial and material resources; economic stimulation of rational use and protection of lands

15) land information management - access to public information; open data sets; transparency of government activities.

Conclusions and prospects. The approaches proposed in the discussion to outline the subject area of knowledge "Geodesy and Land Management" can be used in the training and certification of higher education and scientific personnel of higher qualification, development of standards of higher education, planning and implementation of research, reviewing scientific publications, development of targeted scientific and scientifictechnical programs in relevant fields, etc.

\section{References}

1. Voitenko S., Tretiak K., Shults R. Perspektyvy rozvytku inzhenernoi heodezii v Ukraini. Suchas. dosiahnennia heodez. nauky ta vyr-va. 2011. Vyp. 2. S. 24-27.

2. Dobriak D., Martyn A., Kovalchuk I., Budziak V., Dorosh O., Kokhan S., Loik H. Pidhotovka fakhivtsiv i naukovtsiv iz zemleustroiu ta zemelnoho kadastru: yak vyrishuvaty problemy? Zemlevporiadnyi visnyk. 2013. № 11. S. 9-13.

3. Martyn A.G., Avramchuk B.O. Rehuliuvannia zemleustroiu u Yevropeiskomu Soiuzi: napriamy adaptatsii dlia Ukrainy // Zemleustrii, kadastr i monitorynh zemel. — 2018. — № 1. - S. 4-13. 
4. Sossa R.I., Trevoho I.S. Kudy rukhaietsia ukrainska heodeziia ta kartohrafiia? Visn. heodezii ta kartohrafii. 2015. № 5/6. S. 6-12.

5. FIG Definition of the Functions of the Surveyor, 2003. URL: https://www.fig.net/news/archive/news_2003/FIG_definition_of_surveyor_2003_fin.asp

6. European requirements for cadastral surveyor activities, 2008. URL: http://www.clge.eu/documents/events/206/cadastral_surveyor_acitivities_report.pdf

Мартин А.Г., Тревого І.С., Свсюков Т.О., Бурштинська Х.В. ДО ПИТАННЯ ПРО ВИЗНАЧЕННЯ ПРЕДМЕТНОЇ ОБЛАСТІ ДОСЛЦДЖЕНЬ ЗА СПЕЦАЛЬНІСТЮ «ГЕОДЕЗІЯ ТА ЗЕМЛЕУСТРІЙ»

Анотація. У статті в порядку обговорення запропоновано зміст предметної області запровадженої у 2015 ройі в Україні спеціальності «Геодезія та землеустрій» як множини всіх предметів, властивості яких $і$ відношення між якими мають розглядатися у відповідній науковій теорії. На підставі усталеної практики дослідниџької роботи, а також міжнародних підходів до визначення предмету сучасних геодезії та землеустрою, запропоновано виділити шість підмножин області досліджень (спеціалізащій): геодезія; аерокосмічні дослідження Землі, фотограмметрія та геоінформатика; картографія; земельний кадастр; землеустрій; управління земельними ресурсами. Для кожної із підмножин предметної області досліджень запропоновано детальний опис предметної спрямованості, щзо дозволяе конкретизувати контекст та зміст відповідних досліджень. Детальний опис предметної області галузі знань дозволяє спростити здобувачам наукових ступенів та їх науковим керівникам вибір потрібного напряму досліджень, а також процес підготовки $i$ оформлення документів. Чітке окреслення предметної області галузі знань також дозволяє закладам вищої освіти ефективніше розбудовувати відповідні освітні програми, належним чином розвивати професійну сферу свого функціонування. Редакційні колегї фахових 
наукових видань можуть використовувати опис предметної області галузі знань для встановлення відповідності поданих авторами статей спеціалізації таких видань.

Ключові слова: геодезія, землеустрій, предметна область, сфера досліджень, доктор філософії, вища освіта.

Мартын А.Г., Тревого И.С., Евсюков Т.А., Бурштынская Х.В.

К ВОПРОСУ ОБ ОПРЕДЕЛЕНИИ ПРЕДМЕТНОЙ ОБЛАСТИ ИССЛЕДОВАНИЙ ПО СПЕЦИАЛЬНОСТИ ЩГЕОДЕЗИЯ И ЗЕМЛЕУСТРОЙСТВО»

Аннотация. Аннотация. В статье в порядке обсуждения предложено содержание предметной области, введенной в 2015 году в Украине специиальности «Геодезия и землеустройство» как множества всех предметов, свойства которых и отношения между которыми должны рассматриваться в соответствующей научной теории. На основании сложивщейся практики исследовательской работы, а также международных подходов к определению предмета современных геодезии и землеустройства, предложено выделить шесть подмножеств области исследований (спещиализаџий): геодезия; аэрокосмические исследования Земли, фотограмметрия и геоинформатика; картография; земельный кадастр; землеустройство; управления земельными ресурсами. Для каждой из подмножеств предметной области исследований предложено подробное описание предметной направленности, позволяет конкретизировать контекст $u$ содержание соответствующих исследований. Детальное описание предметной области знаний позволяет упростить для соискателей ученых степеней и их научным руководителям выбор нужного направления исследований, а также процесс подготовки и оформления документов. Четкое определение предметной области знаний также позволяет учреждениям высшего образования эффективнее развивать соответствующче образовательные программы, 
должным образом развивать профессиональную сферу своего функиионирования. Редакиионные коллегии профессиональных научных изданий могут использовать описание предметной области знаний для установления соответствия представленных авторами статей специализации таких изданий.

Ключевые слова: геодезия, землеустройство, предметная область, сфера исследований, доктор философии, выстее образование. 